\title{
GENRE-BASED ANALYSIS OF THE REALISATION OF CONCESSION IN JUDICIAL DISCOURSE
}

\begin{abstract}
The article aims to contribute a genre-based description of the realisation of Concession in EU judicial discourse. The analysis has been carried out on a corpus of judgments issued by the EU court of last instance, i.e. the European Court of Justice with the intention to identify the patterns and markers of Concession in judicial argumentation.

In the analysis the author used the concept of Concession developed by Couper-Kuhlen and Thompson $(1999,2000)$ following the assumptions underlying Interactional Linguistics. The results revealed the most frequent patterns and markers of Concession in judicial discourse. At the same time, they led the author to the conclusion that the interactional model of Concession developed for analysing the spoken mode of language may successfully be applied in the examination of written data.
\end{abstract}

\section{Introduction}

Nowhere are the challenges imposed by the skillful use of language more evident than in the realm of law. And yet, even though the inseparable relationship between language and law has been studied by legal scholars and linguists alike, judicial argumentation has been analysed mainly from the point of view of legal theory and legal philosophy. As a consequence, the importance of linguistic elements in the construction of argumentation in judicial texts has not received due attention. ${ }^{1}$

This article aims at bridging the gap between legal argumentation theory and linguistic discourse analysis by examining one discourse relation that should not be denied its importance in the architecture of judicial argumentation, namely

${ }^{1}$ Among the few linguistic studies on judicial argumentation are analyses carried out by Mazzi $(2005,2006,2007)$, in which the author investigates linguistic constituents of argumentative discourse in judicial texts. 
the discourse-pragmatic relation of Concession. In particular, the author's goal was to analyse lexical and syntactic features of the written mode that are relevant in the realisation of Concession. Further, it was the author's intention to examine the patterns and signals that indicate the Concessive relation, as well as their distribution in the context of one legal genre.

The analysis aims to contribute a genre-based description of the realisation of Concession in EU judicial discourse. However, it is intended to be exploratory rather than definitive. The study has been carried out on a corpus of ten judgments issued by the European Court of Justice. ${ }^{2}$ Thanks to the adoption of a genre-based approach, it was possible to analyse the Concessive relation within the generic structure of judgments. Accordingly, the discussion has been confined to the occurrences of Concessive patterns in the argumentative move of judgments: Arguing the case, including the Court's own argumentation, as well as reported arguments. The other moves have been excluded from the analysis.

\section{Concessive relation revisited}

Closely related to causality, condition and adversativity, concession was first investigated as a rhetorical figure in argumentation. Originally, the figure of concessio (derived from the Latin verb concēdere) meant conceding the adversary's point in order to strengthen one's position. Centuries later, a number of linguists adopted the semantic-syntactic approach to the study of concession, thus focusing primarily on relations holding between clauses (see for instance: Pisarkowa 1974, Grochowski 1976, Rudolph 1996, Grote et al. 1997, Crevels 2000, König and Siemund 2000, Verhagen 2000). Needless to say, in these traditional methodologies little attention is paid to the pragmatic uses of concession and the manner in which concessive clauses function in a specific context. More recently, however, thanks to renewed interest in this linguistic phenomenon, concession has been placed in the domain of pragmatics and viewed as a discourse-pragmatic relation.

Notably, concession was described as a discourse phenomenon, beside other rhetorical relations, under Rhetorical Structure Theory (RST), whose authors Mann and Thompson (1988) defined it as a strategy to increase the reader's (hearer's) positive regard for the information presented in the nucleus of the sentence. The RST framework was later complemented by the concept of Concession $^{3}$ advanced by Couper-Kuhlen and Thompson $(1999,2000)$ which, in turn, was further refined by Barth-Weingarten $(2000,2003)$. In their interactional model, Concession is realised, prototypically, as a three-part sequence consisting of three moves: claim (X), acknowledgment ( $\left.\mathrm{X}^{\prime}\right)$ and counterclaim (Y). It requires (at least) two participants with the first one producing the claim

\footnotetext{
${ }^{2}$ Further in the article the European Court of Justice is referred to either as the ECJ or the Court.

3 "Concession" understood as a sequential relation in the action-oriented approach is capitalised, while "concession" understood as the act of conceding only starts with a lower-case letter.
} 
and the other acknowledging it only to refute it with a stronger counterclaim. This is how Concession will be understood in the present analysis: as a sequential discourse-pragmatic relation.

\section{Concession as a discourse-pragmatic relation in written discourse}

The action-oriented approach to Concession highlights its dyadic nature. What is more, unlike in previous studies, the patterns and signals indicating the relation are analysed in real speech rather than in idealised and decontextualised settings. The analysis has evolved from the assumptions underlying Interactional Linguistics taking into account the fact that the actual realisation of Concession, as mentioned above, is conditioned by social interaction involving at least two interlocutors. However, as research by Barth-Weingarten (2003) shows, monologic patterns, though not very frequent in talk, constitute an important variation from the prototypical realisation of Concession (Barth-Weingarten 2003: 74).

Unsurprisingly, monadic variations as well as pseudo-dyadic schemata figure more prominently in the written mode than in speech. Their presence suggests that not only speakers, but also writers are aware of, and follow the three-part basic pattern of Concession that occurs in spoken language. Therefore, even though the action-oriented concept of Concession has been originally designed for studying the oral mode, this analysis is intended to show that it can successfully be applied to Concessive patterns that occur in the written mode. This approach contrasts with previous studies on concession in written language focusing mainly on concessive constructions in invented examples and concerned mainly with the identification of certain established connectives.

As has been indicated above, parallels can be found between written and spoken grammars. Thus, "written Concessive structures can be seen as the product of a 'mute' dialogue between the writer and a (temporally and spatially separated) reader" (Barth-Weingarten 2003: 75). It might also be noted that while participants in a conversation are involved in the negotiating of meaning, the writer is addressing a range of potential readers (Ford 1994: 549 in Barth-Weingarten 2003: 75). By analogy to speakers, writers appear to acknowledge possible, though not yet expressed objections and to forestall them. Still, since there are different requirements of language production and processing in speech as well as in writing and since different degrees of editedness are typical of the two language modes, different Concessive patterns prevail in spoken and written data (Barth-Weingarten 2003: 204).

Two basic monologically produced Concessive sequences can be identified in written language: the Pseudo-Dyadic Schema and the Monadic Schema. ${ }^{4}$ These, in turn, have further variations: the Reversed Pseudo-Dyadic Schema and the Reversed Monadic Schema. In Pseudo-Dyadic variants the entire pattern is produced by one participant who first triggers the Concessive sequence by as-

\footnotetext{
${ }^{4}$ The following description of monologic Concessive patterns is based on the framework developed by Barth-Weingarten (2003).
} 
suming an opposing view, secondly acknowledges the preceding claim, and thirdly produces a counterclaim that downgrades the conceded proposition. As can be seen in Figure 1, the Pseudo-Dyadic Schema has its reversed variation with the initial proposition first followed by a counterclaim and next by a postposed acknowledging move negating the grounds for a possible objection. In the Monadic Schema, on the other hand, even though the initial claim is missing, it is strongly projected and thus it can be conceded in the following move. Next, the author produces a counterclaim to express his or her preferred position. The Monadic Schema and its two reversed variants - with a reordered sequence of moves - have been illustrated in Figure 2.

Figure 1. Pseudo-Dyadic Schemata

Figure 1.1. Pseudo-Dyadic Concessive Schema (PD)

\begin{tabular}{|c|c|c|c|}
\hline PARTICIPANT & $\begin{array}{l}\text { MOVE } \\
\text { SYMBOL }\end{array}$ & MOVE & MOVE DESCRIPTION \\
\hline \multirow[t]{3}{*}{ A: } & $\mathbf{X}$ & Claim & $\begin{array}{l}\text { Author A assumes an opposing } \\
\text { point of view of Author B or (in } \\
\text { the absence of the other interac- } \\
\text { tant / other interactants) reports } \\
\text { a third party's argumentation (e.g. } \\
\text { argumentation presented by } \\
\text { a court of lower instance, appel- } \\
\text { lant, the Council, a government, } \\
\text { etc.) }\end{array}$ \\
\hline & $\mathrm{X}^{\prime}$ & Acknowledgment & $\begin{array}{l}\text { Preposed acknowledging move / } \\
X^{\prime} \text { negates the grounds for a pos- } \\
\text { sible objection }\end{array}$ \\
\hline & $\mathbf{Y}$ & Counterclaim & $\begin{array}{l}\text { Counterargument / the author's } \\
\text { preferred position }\end{array}$ \\
\hline
\end{tabular}

Figure 1.2. Reversed Pseudo-Dyadic Schema (RPD)

\begin{tabular}{|c|c|c|c|}
\hline PARTICIPANT & $\begin{array}{l}\text { MOVE } \\
\text { SYMBOL }\end{array}$ & MOVE & MOVE DESCRIPTION \\
\hline \multirow[t]{3}{*}{ A: } & $\mathbf{X}$ & Claim & $\begin{array}{l}\text { Author A assumes an opposing } \\
\text { point of view of Author B or (in } \\
\text { the absence of the other interac- } \\
\text { tant / other interactants) reports } \\
\text { a third party's argumentation (e.g. } \\
\text { argumentation presented by } \\
\text { a court of lower instance, appel- } \\
\text { lant, the Council, a government, } \\
\text { etc.) }\end{array}$ \\
\hline & $\mathbf{Y}$ & Counterclaim & $\begin{array}{l}\text { Counterargument / the author's } \\
\text { preferred position }\end{array}$ \\
\hline & $\mathrm{X}^{\prime}$ & Acknowledgment & $\begin{array}{l}\text { Postposed acknowledging move / } \\
X \text { ' negates the grounds for a pos- } \\
\text { sible objection }\end{array}$ \\
\hline
\end{tabular}


Figure 2. Monadic Schemata

Figure 2.1. Monadic Concessive Schema (M1)

$\begin{array}{llll}\text { PARTICIPANT } & \begin{array}{l}\text { MOVE } \\ \text { SYMBOL } \\ \mathbf{0}\end{array} & \text { MOVE } & \text { MOVE DESCRIPTION } \\ \text { A: } & \mathbf{X}, & \begin{array}{l}\text { Claim } \\ \text { Acknowledgment }\end{array} & \begin{array}{l}\text { Implied claim } \\ \text { Preposed acknowledging move / } \\ \text { X' negates the grounds for a pos- } \\ \text { sible objection } \\ \text { Counterargument / the author's } \\ \text { preferred position }\end{array} \\ \text { Y } & \text { Counterclaim } & \text { and }\end{array}$

Figure 2.2. Reversed Monadic Schema (RM1)

\begin{tabular}{|c|c|c|c|}
\hline \multirow[t]{2}{*}{ PARTICIPANT } & $\begin{array}{l}\text { MOVE } \\
\text { SYMBOL }\end{array}$ & MOVE & MOVE DESCRIPTION \\
\hline & $\mathbf{0}$ & Claim & Implied claim \\
\hline \multirow[t]{3}{*}{ A: } & $\mathbf{Y}$ & Counterclaim & $\begin{array}{l}\text { Counterargument / the author's } \\
\text { preferred position }\end{array}$ \\
\hline & $\mathrm{X}^{\prime}$ & Acknowledgment & $\begin{array}{l}\text { Insertion of acknowledgment / } \mathrm{X} \text { ' } \\
\text { negates the grounds for a possible } \\
\text { objection }\end{array}$ \\
\hline & $\mathbf{Y}^{\prime}$ & $\begin{array}{l}\text { Return } \\
\text { to counterclaim }\end{array}$ & Repeated earlier point \\
\hline
\end{tabular}

Figure 2.3. Reversed Monadic Schema (RM2)

\begin{tabular}{|c|c|c|c|}
\hline \multirow[t]{2}{*}{ PARTICIPANT } & $\begin{array}{l}\text { MOVE } \\
\text { SYMBOL }\end{array}$ & MOVE & MOVE DESCRIPTION \\
\hline & $\mathbf{0}$ & Claim & Implied claim \\
\hline \multirow[t]{2}{*}{ A: } & $\mathbf{Y}$ & Counterclaim & $\begin{array}{l}\text { Counterargument / the author's } \\
\text { preferred position }\end{array}$ \\
\hline & $\mathrm{X}^{\prime}$ & Acknowledgment & $\begin{array}{l}\text { The acknowledging move ends } \\
\text { the sequence (backing down) }\end{array}$ \\
\hline
\end{tabular}

It might be noted that to date (to the best of the author's knowledge) no linguistic analysis of the interactional model of Concession has been carried out with regard to judicial texts.

\section{Judicial discourse}

Since legal language is too broad a term to be analysed as a homogenous entity, it has been postulated that its registers, genres and varieties should be studied rather than legal language as such (Kurzon 1997). Before a description of one legal genre, i.e. judgment presented further in this article, it appears justified to place it within the judicial discourse community to which it belongs. 
The notion of "discourse community," advanced by Swales (1990), describes a group of individuals who are "bound by a common interest, who communicate through approved channels and whose discourse is regulated" (Porter 1986: 38). In the context of the present study, the discourse community is that of judges and their audience. An effective illustration of the judicial discourse community has been suggested by Vannier (2001 in Mazzi 2007: 27):

Figure 3. Judicial discourse community (Vannier 2001)

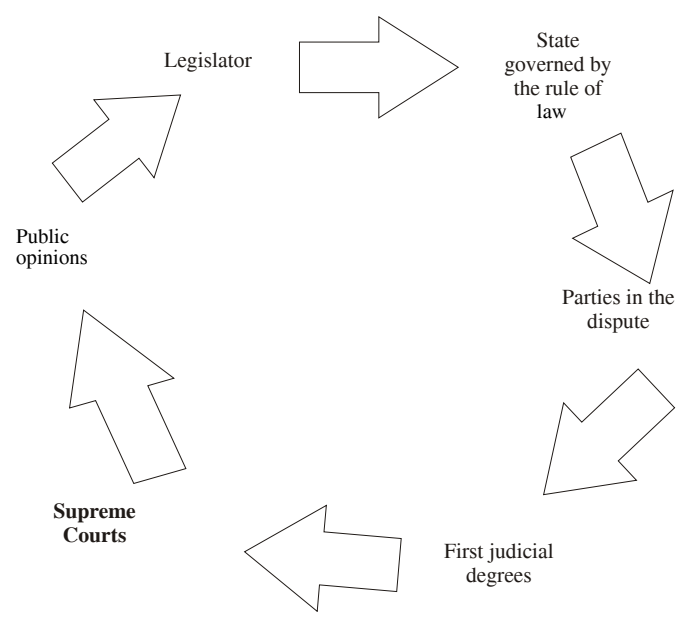

Even though Vannier's model shows legal communication in a single state, it may well be adapted to represent such interaction in the EU context as illustrated in Figure 4:

Figure 4. Judicial discourse community in the EU (adapted from Vannier 2001)

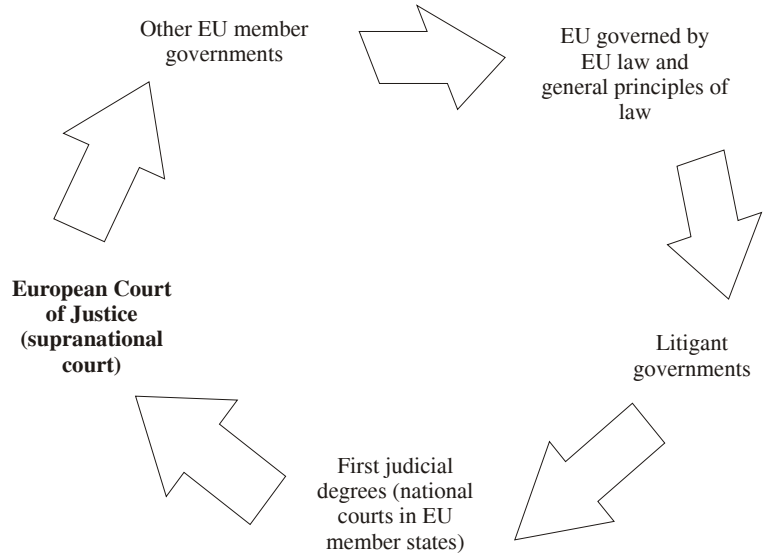

While the role of the ECJ is to review compatibility of the national legislation of Member States with Community law, the communicative purpose of its judges is to settle supranational disputes with litigant governments by 
"presenting well-founded arguments in support of a judicial conclusion through which a number of more or less controversial facts are interpreted within the framework of a valid legal order" (Mazzi 2007: 27). The channel through which they communicate with "the composite audience" - including those who are interested in the development of the law (legal audience), as well as those directly (litigant audience) or indirectly (general audience) affected by the Court's decision-

-making (see Pincoff 1971) - is the genre of judgments.

\section{Genre analysis of ECJ judgments}

Viewed as the study of situated linguistic behaviour carried out for different purposes and at different levels, genre analysis aims, among other goals, to account for the realities of the world of texts and for socially recognised communicative purposes. Textual artefacts are studied "in the context of specific institutional and disciplinary practices, procedures and cultures in order to understand how members of specific discourse communities construct, interpret and use these genres to achieve their community goals and why they write them the way they do" (Bhatia 2002: 6). Various methods are applied in the study of genres: be it ethnographic, socio-cognitive or pedagogical perspectives, to name but a few. Nonetheless, while the interdiscursive genre analysis espoused by Bhatia should not be denied its relevance, in the present genre analysis of ECJ judgments the textual and socio-pragmatic approaches have been adopted.

Bhatia (1993), who analyses the genre of common law cases, outlines a four-move structure of judgments. He maintains, however, that the generic structure of judgments should be seen as flexible, since, as he further points out, some moves may be brief, while others may be more elaborate and they may contain embedded steps (Bhatia 1993: 136). A case in point one can refer to is that of ECJ judgments that clearly have more moves than the judgments analysed by Bhatia. The moves that can be identified in ECJ judgments are as follows: Identification of the case (Move 1), Identification of the scope of proceedings (Move 2), Reference to Community law and / or national legislation (Move 3), History of the case (Move 4), Arguing the case (Move 5), Settlement of costs (Move 6) and Pronouncement of judgment (Move 7). ${ }^{5}$

Figure 5. Generic structure of judgments issued by the ECJ

Move 1 - Identification of the case

Move 2 - Identification of the scope of proceedings

\footnotetext{
${ }^{5}$ A similar genre analysis of judgments issued by courts of last instance (European Court of Justice, House of Lords and Ireland's Supreme Court) has been carried out by Mazzi (2007), who adopts a genre perspective when analysing the discursive construction of judicial argumentation. Likewise, Le et al. (2008) present an analysis of rhetorical segments and their functions in judgments issued by Chinese and American courts of first instance.
} 
Move 3 - Reference to Community law and / or national legislation

Move 4 - History of the case

Move 5 - Arguing the case

Move 6 - Settlement of costs

Move 7 - Pronouncement of judgment

It should be pointed out that Move 5: Arguing the case can further be subdivided into two subsequent steps: Arguments of the parties and Findings of the Court. It is the second step of this move that is most relevant in the context of this analysis, since it includes the ECJ's view on its competence to review the case and, further, its determination regarding the admissibility of the questions referred for a preliminary ruling. Naturally, apart from reporting the arguments put forward by the litigant parties or other courts, the ECJ presents its own line of reasoning that leads it to arrive at the pronouncement of judgment. As can be expected, the main function of Move 5 is to argue the case and to refute or to concede the arguments submitted by the litigant parties (see Figure 6).

Figure 6. Functions of individual moves in ECJ judgments

\section{MOVE}

Move 1 - Identification of the case

Move 2 - Identification of the scope of proceedings

Move 3 - Reference to Community law and / or national legislation

Move 4 - History of the case

Move 5 - Arguing the case

Move 6 - Settlement of costs

Move 7 - Pronouncement of judgment

\section{FUNCTION}

Informative

Informative

Informative

Informative

Argumentative

Performative

Performative

Move 5: Arguing the case has been used to build a corpus for the analysis of the realisation of the Concessive relation in judicial texts in the context of the genre of judgment.

\section{Corpus and data}

The study was conducted on a small corpus of ten ECJ judgments composed of 22,629 words. ${ }^{6}$ The specimens were selected randomly out of the collection of judgments issued in the period between 1 January 2006 and 31 December 2006. It should be stressed that the jurisprudential area of the judgments was not a relevant criterion during the collection of data. As a result, the judgments included in the corpus concern various issues, e.g. competition, social security for

\footnotetext{
${ }^{6}$ The word count provided refers to the number of words in the sections of the judgments used to compile the corpus (Move 5: Arguing the case) and not to the total number of words in the judgments selected for the analysis.
} 
migrant workers or police and judicial cooperation in criminal matters. All the judgments were downloaded from the EU case-law database available at: http://curia.europa.eu/jurisp/cgi-bin/form.pl?lang=en that provides texts of judgments, among other documents, issued by Community courts.

\section{Realisation of Concession in ECJ judgments - analysis of corpus data}

\section{Patterns}

At the outset of the discussion of the corpus data it must be made clear that only distinct instances of Concession have been included in the analysis. Conversely, questionable examples in Move 5: Arguing the case (with no clear three-move sequence) have been excluded from the scope of this study. Further, as regards the formal composition of the Concessive sequence and its constitutive units, it might first be noted that in oral data TCU (turn-constructional units) are used to determine the size of the moves. In speech the moves are adjacent and they are clearly recognisable not only thanks to discourse markers but also thanks to partitioning or prosodic means, even if explicit signals are absent (see Łyda 2007: 105-106). However, in written discourse Concessive moves are not always placed contiguously - which holds true especially in the case of judicial texts notorious for their syntactic complexity and extraordinary length of sentences - and, what is more, the size of the moves can be reduced (where no explicit claim is present) or expanded (where paraphrases, supplementary information or further reasons are added). Thus, the Concessive moves found in the corpus include fragments of sentences, full sentences, or even whole paragraphs, which, in turn, build the Concessive patterns defined in the action-oriented approach.

As a result of a thorough manual analysis of the texts compiled in the corpus, 26 Concessive sequences have been recognised, realised as the following monologic Concessive patterns: Pseudo-Dyadic Schema, Reversed Pseudo-Dyadic Schema, Monadic Schema and Reversed Monadic Schema 1. Interestingly, no instantiations of the Reversed Monadic Schema 2 have been found. By contrast, the most frequent pattern, found both in the Court's own argumentation and reported arguments, was that of the Reversed Monadic Schema 1 (A: 0 Y X' Y') accounting for $46.2 \%$ of all occurrences. On the other hand, $23.1 \%$ of all Concessive sequences exemplified the Monadic Schema (A: 0 X' Y), whereas a slightly smaller proportion (19.2\%) represented the Reversed Pseudo-Dyadic pattern (A: X Y X'). Finally, the Pseudo-Dyadic Schema (A: X X' Y) was detected in $14.5 \%$ of all examples. Notably, out of all Concessive sequences $84.6 \%$ were found in the Court's own arguments, whereas only $15.4 \%$ occurred in reported arguments. 
Figure 7. Distribution of Concessive patterns in the corpus

Figure 7.1. All instances of Concessive patterns

\begin{tabular}{|l|c|c|}
\hline Pattern & $\begin{array}{c}\text { Number } \\
\text { of occurrences }\end{array}$ & \% of all occurrences \\
\hline$P D\left(A: X X^{\prime} Y\right)$ & 3 & 11.5 \\
\hline$R P D\left(A: X Y X^{\prime}\right)$ & 5 & 19.2 \\
\hline$M 1\left(A: 0 X^{\prime} Y\right)$ & 6 & 23.1 \\
\hline$R M 1\left(A: 0 Y X^{\prime} Y^{\prime}\right)$ & 12 & 46.2 \\
\hline$R M 2\left(A: O Y X^{\prime}\right)$ & 0 & 0 \\
\hline Total & $\mathbf{2 6}$ & - \\
\hline
\end{tabular}

Figure 7.2. Instances of Concessive patterns in the Court's own argumentation

\begin{tabular}{|l|c|c|}
\hline Pattern & $\begin{array}{c}\text { Number } \\
\text { of occurrences }\end{array}$ & $\begin{array}{c}\text { \% of all occurrences in } \\
\text { Court's argumentation }\end{array}$ \\
\hline$P D\left(A: X X^{\prime} Y\right)$ & 2 & 9.1 \\
\hline$R P D\left(A: X Y X^{\prime}\right)$ & 4 & 18.2 \\
\hline$M 1\left(A: O X^{\prime} Y\right)$ & 6 & 27.3 \\
\hline$R M 1\left(A: O Y X^{\prime} Y^{\prime}\right)$ & 10 & 45.4 \\
\hline$R M 2\left(A: O Y X^{\prime}\right)$ & 0 & 0 \\
\hline Total & $\mathbf{2 2}$ & - \\
\hline
\end{tabular}

Figure 7.3. Instances of Concessive patterns in reported argumentation ${ }^{7}$

\begin{tabular}{|l|c|c|}
\hline Pattern & $\begin{array}{c}\text { Number } \\
\text { of occurrences }\end{array}$ & $\begin{array}{c}\text { \% of all occurrences } \\
\text { of reported Concession }\end{array}$ \\
\hline$P D\left(A: X X^{\prime} Y\right)$ & 1 & 25 \\
\hline$R P D\left(A: X Y X^{\prime}\right)$ & 1 & 25 \\
\hline$M 1\left(A: 0 X^{\prime} Y\right)$ & 0 & 0 \\
\hline$R M 1\left(A: 0 Y X^{\prime} Y^{\prime}\right)$ & 2 & 50 \\
\hline$R M 2\left(A: O Y X^{\prime}\right)$ & 0 & 0 \\
\hline Total & $\mathbf{4}$ & - \\
\hline
\end{tabular}

Annotated excerpts from ECJ judgments illustrating the patterns and signals recognised in the corpus can be found in Appendix 2 to this article.

\section{Signalling}

Certainly, the purpose of the analysis was not only to distinguish Concessive patterns occurring in the corpus, but also to identify signals that co-occur with the Concessive relation. Yet, though linguistic exponents of concessivity have been defined in numerous studies and a wide range of discourse coherence rela-

\footnotetext{
${ }^{7}$ The figures refer only to instances of reported Concession in Move 5: Arguing the case. Instances of reported Concession found in the other moves have been excluded from the analysis.
} 
tions has been produced (see for instance: Halliday and Hasan 1976, Sanders et al. 1992, Knott 1996, Grote et al. 1997, Oates 2000), there is no unanimity as regards the definition of the relation that they mark. What is more, one needs to take into account the fact that apart from exemplary markers believed to mark one relation only, there are those that are multifunctional and that can cue several relations. On the other hand, primary exponents of concession, such as conjunctions although or even though, ${ }^{8}$ may not always mark Concession understood as an interactional sequence.

Notice should also be taken of the claim that the Concessive relation may lack explicit signalling, i.e. that it is not cued by way of exemplary concessive markers. The claim holds true for oral data; however, the analysis carried out on ECJ judgments does not seem to confirm the hypothesis with reference to written discourse. In a similar vein, Taboada (2006) who investigated text relations in written data (newspaper articles) found that Concession was marked in 90.35\% of all instances (as opposed, for instance, to Elaboration that was cued in $9.79 \%$ of all occurrences). This, of course, can be explained by the fact that writers do not have at their disposal such an extensive repertoire of signals as speakers, who interact and negotiate meaning with the co-present interlocutors and who may rely on, apart from discourse markers, prosodic devices such as stress or intonation, or even body language that helps them to convey extralinguistic messages.

Given the above, the methodical reading of ECJ judgments resulted in the selection of the most recurrent signals associated with Concession, including such conjunctions as although or even though, such conjuncts as however or nevertheless, such modal verbs as may or might, such attitudinal disjuncts as rightly or merely or the emphatic $d o$. It was revealed that however was by far the most frequent Concessive signal (22\% of all occurrences). The second most frequent cue was although (9.9\% of all examples), followed by may (7.7\%), rightly (5.5\%), nevertheless alongside the emphatic do (both found in $4.4 \%$ of all occurrences), and finally the concessive verb acknowledge and the attitudinal disjunct in principle playing the role of a truth-evaluator ${ }^{9}$ (with $3.3 \%$ of all examples each). At the bottom of the list featuring the most frequent Concessive markers in Figure 8 (with 2.2\% of all occurrences each) are: could, merely, none the less, only where, and the truth-evaluating phrase the fact remains that. Other signals that occurred once only have not been included in Figure 8, but they can be found in Appendix 1 at the end of this article.

\footnotetext{
${ }^{8}$ It must be noted here that since various methodological approaches are adopted, there is no agreement regarding terminological classification of such conjunctions as although or even though. Although alone is referred to, for instance, as "subordinating conjunction" (Quirk and Greenbaum 1973), "concessive connective" (König 1988) or "adversative connective" (Knott and Dale 1994). In fact, the terms provided are not mutually exclusive, yet their meanings in different taxonomies are not exactly the same.

${ }^{9}$ See Łyda (2007: 146-149) for a discussion of Concessive markers labelled as truth-evaluation elements (or truth-evaluators) including modals of possibility and necessity, disjuncts and other expressions marking the speaker's attitude. An informative analysis of the role of evaluative disjuncts in concessive relations can also be found in Thompson and Zhou (2000).
} 
Figure 8. The most frequent Concession signals in the corpus

\begin{tabular}{|c|c|c|c|}
\hline Signal & Type of signal & $\begin{array}{c}\text { Number of } \\
\text { occurrences }\end{array}$ & $\begin{array}{c}\text { \% of all Concessive } \\
\text { signals }\end{array}$ \\
\hline however & Concessive disjunct & 20 & 22 \\
\hline although & Concessive conjunction & 9 & 9.9 \\
\hline may & Modal of possibility & 7 & 7.7 \\
\hline rightly & Attitudinal disjunct & 5 & 5.5 \\
\hline nevertheless & Concessive disjunct & 4 & 4.4 \\
\hline emphatic 'do' & Other signal & 4 & 4.4 \\
\hline acknowledge & Concessive verb & 3 & 3.3 \\
\hline in principle & Attitudinal disjunct & 3 & 3.3 \\
\hline could & Modal of possibility & 2 & 2.2 \\
\hline merely & Attitudinal disjunct & 2 & 2.2 \\
\hline none the less & Concessive disjunct & 2 & 2.2 \\
\hline only where & Conditional conjunction & 2 & 2.2 \\
\hline the fact remains & Truth-evaluation phrase & 2 & 2.2 \\
\hline that & & & \\
\hline
\end{tabular}

As follows from the preceding paragraph, Concessive signals found in the corpus are not confined to traditional concessive markers signalling relations between clauses. Instead, as the analysis revealed, they are varied and encompass the categories of markers mentioned above.

It should also be pointed out that co-occurrence of Concessive signals is a frequent phenomenon, which can be observed in the following examples:

1. While the view may rightly be taken that ...

2. It may nevertheless provide ...

3 . ... the unrecovered entitlements at issue could none the less legitimately be ...

The above instances support the view adopted by Oates (2000: 41), who argues that one relation may be cued by multiple markers. Thus, occurrence of more than one marker does not always signal a number of discourse relations; instead, they often cue one relation. What is more, as Oates aptly observes, weak markers (that can signal more than one relation) always precede the strong ones (that can cue only one relation). If their order was reversed, the sentence(s) would no longer be grammatically correct (Oates 2000: 44). Constructing a hierarchy of discourse markers that signal Concession in judicial texts might yield interesting results. Yet, given the limited length of this article, the issue cannot be addressed here.

On the other hand, distribution of the most frequent Concessive signals was included in the scope of the analysis. As expected, the study makes clear that the most frequent signal however occurred mostly in the counterclaim (80\%). On the other hand, although was found mainly in acknowledgments (88.9\% of all 
the occurrences of this conjunction). Whereas most of the signals occurred both in the acknowledging move and in the countermove, the concessive verb $a c$ knowledge was found only in acknowledgments and the emphatic do marked only the counterclaim. Unsurprisingly, the majority of Concessive signals $(89.2 \%)$ was recognised in the Court's own argumentation. By contrast, only $10.8 \%$ of all examples represented reported Concession.

Figure 9. Distribution of the most frequent Concession signals in the corpus

\begin{tabular}{|c|c|c|c|}
\hline \multirow[t]{3}{*}{ SIGNAL } & \multirow{3}{*}{$\begin{array}{c}\text { TOTAL } \\
\text { NUMBER OF } \\
\text { OCCURRENCES }\end{array}$} & \multirow{2}{*}{\multicolumn{2}{|c|}{$\begin{array}{c}\text { NUMBER OF OCCURRENCES IN MOVES } \\
\text { MOVE }\end{array}$}} \\
\hline & & & \\
\hline & & ACKNOWLEDGMENT & COUNTERCLAIM \\
\hline however & 20 & 4 & 16 \\
\hline although & 9 & 8 & 1 \\
\hline may & 7 & 3 & 4 \\
\hline rightly & 5 & 2 & 3 \\
\hline nevertheless & 4 & 1 & 3 \\
\hline emphatic 'do' & 4 & - & 4 \\
\hline acknowledge & 3 & 3 & - \\
\hline in principle & 3 & 1 & 2 \\
\hline could & 2 & 1 & 1 \\
\hline merely & 2 & - & 2 \\
\hline none the less & 2 & - & 2 \\
\hline only where & 2 & - & 2 \\
\hline $\begin{array}{c}\text { the fact remains } \\
\text { that }\end{array}$ & 2 & 1 & 1 \\
\hline
\end{tabular}

\section{Corpus data against previous findings}

It appears relevant to present the corpus data against previous findings. An interesting observation is that although is the second most frequent exponent of concessivity in three different analyses of written data (see Figure 10 and 11). The marker can be found in the results obtained by Rudolph (1996), who analysed concession as a clausal relation, those presented by Taboada (2006), whose research followed the RST paradigm, and in the data obtained in the present study investigating Concession as a sequential relation in the action-oriented approach. However, the most frequent Concessive signal in the corpus, though not so commonly applied by the authors of the texts studied by Taboada (2006), was nevertheless among the most frequent concessive markers recognised by this researcher. Rudolph (1996), on the other hand, did not identify it as one of the most frequent concessive markers in her corpus. The other concessive markers recognised by the two analysts were also identified in the present corpus (see Appendix 1), but they were not as frequent as in the other two corpora.

Thus, it may be assumed that even if different concepts of concession in written language are applied, there is likely to be some correlation between the 
findings obtained. Needless to say, differences in marking are expected to be found, regardless of the adopted approach, between concessive signals found in written language and those identified in speech. Notably, research undertaken by Barth-Weingarten (2003) reveals that but, occurring in more than $90 \%$ of all Concessive sequences in her corpus, is by far the most frequent Concessive signal in spoken interactions. In the present analysis, by contrast, no instances of the Concessive use of but have been recorded.

Figure 10. The most frequent Concession signals in the corpus $v$. the most frequent connectives and conjuncts associated with concession and identified in written data by Rudolph (1996)*

\begin{tabular}{|c|c|}
\hline Corpus data & Rudolph data \\
\hline however & though \\
\hline although & although \\
\hline may & in spite of \\
\hline rightly & despite \\
\hline nevertheless & even though \\
\hline emphatic 'do' & even when \\
\hline acknowledge & ...though... \\
\hline in principle & although - in fact \\
\hline could & although - nevertheless \\
\hline merely & though - all the same \\
\hline none the less & even if* \\
\hline only where & {$[\ldots]^{*}$} \\
\hline the fact remains that & albeit \\
\hline
\end{tabular}

*Excluding concessive conditionals, except for 'even if'.

Figure 11. The most frequent Concession signals in the corpus v. the most frequent concession signals identified in written data (newspaper articles) by Taboada (2006)

\begin{tabular}{|c|c|}
\hline Corpus data & Taboada data \\
\hline however & but \\
\hline although & although \\
\hline may & though \\
\hline rightly & despite \\
\hline nevertheless & while \\
\hline emphatic 'do' & even though \\
\hline acknowledge & however \\
\hline in principle & still \\
\hline could & even if \\
\hline merely & even when \\
\hline none the less & even \\
\hline only where & yet \\
\hline the fact remains that & whether \\
\hline
\end{tabular}


Finally, for the discussion of the realisation of Concession in judicial discourse to be more revealing, an analysis of the relation's discourse functions, in particular those of the acknowledging move and the counterclaim, should complement the description of its patterns and signals. However, for reasons of space, no such contribution can be made in this article. Still, the author hopes to explore the problem in further research to be able to determine the role of Concession as a rhetoric tool and its function in the organisation of judicial texts.

\section{Conclusions}

Although it is too early to present any conclusive results at this stage, since the research is in its early phase, findings seem to indicate certain trends that will have to be corroborated by a study conducted on a larger corpus. Still, one may venture to say that the interactional model of Concession may successfully be applied in an analysis of written data, since writers evidently follow the three-move sequence of Concession recognised in spoken language. It may also be posited that even if Concession in the written mode is identified on the basis of the same approach that is applied in the study of the spoken mode, there are bound to be differences in the marking of Concessive constructions. Further, even though however and although appear to be the most frequent signals of Concession in written discourse, other types of cues, ignored by traditional approaches to concessivity, are also material in the realisation of this relation (e.g. truth-evaluators or the emphatic $d o$ ).

It would be imprudent to assert that the analysis provides conclusive evidence, though. Nonetheless, the author firmly believes that the study should be a stimulus for further research in this field. In particular, she suggests that the role of Concession in the organisation of argumentative discourse, as well as its role as a rhetoric tool in judicial argumentation be further explored. A contrastive analysis of two legal genres might also prove revealing, providing more data on the realisation and function of the Concessive relation in legal discourse. Finally, to test the validity of the hypothesis that the Concessive relation is language-independent and that it is a frequent discourse phenomenon in the genre of judgment, one might conduct a cross-linguistic analysis of judgments written in two unrelated languages, such as for instance English and Polish.

To conclude, further research on the realisation of the discourse-pragmatic relation of Concession in judicial discourse would certainly provide more insights into the reasons why it is applied in a given context and in a given form, and it would serve as yet another contribution to the linguistic description of judicial argumentation. 


\section{Appendix 1}

Concession signals by category and by frequency of occurrence in the corpus

\begin{tabular}{|c|c|c|c|}
\hline Signal & Type of signal & $\begin{array}{l}\text { Number of occurren- } \\
\text { ces in Concessive se- } \\
\text { quences in Move 5: } \\
\text { Arguing the case }\end{array}$ & $\begin{array}{l}\text { \% of all Concessive } \\
\text { signals in Move 5: } \\
\text { Arguing the case }\end{array}$ \\
\hline & $\begin{array}{l}\text { Markers cooc- } \\
\text { curring with } \\
\text { Concessive } \\
\text { sequences }\end{array}$ & & \\
\hline however & & 20 & 22 \\
\hline although & & 9 & 9.9 \\
\hline nevertheless & & 4 & 4.4 \\
\hline while & & 3 & 3.3 \\
\hline none the less & & 2 & 2.2 \\
\hline only where & & 2 & 2.2 \\
\hline but & & 1 & 1.1 \\
\hline despite & & 1 & 1.1 \\
\hline even if & & 1 & 1.1 \\
\hline even though & & 1 & 1.1 \\
\hline even where & & 1 & 1.1 \\
\hline in so far as & & 1 & 1.1 \\
\hline only for so long & & 1 & 1.1 \\
\hline only if & & 1 & 1.1 \\
\hline only in so far as & & 1 & 1.1 \\
\hline so far as possible & & 1 & 1.1 \\
\hline whilst & & 1 & 1.1 \\
\hline & Modal verbs ${ }^{10}$ & & \\
\hline may & & 7 & 7.7 \\
\hline could & & 2 & 2.2 \\
\hline might & & 1 & 1.1 \\
\hline & Other verbs & & \\
\hline acknowledge & & 3 & 3.3 \\
\hline appear & & 1 & 1.1 \\
\hline deny & & 1 & 1.1 \\
\hline not contest per se & & 1 & 1.1 \\
\hline not deny & & 1 & 1.1 \\
\hline
\end{tabular}

${ }^{10}$ Łyda (2007) includes modal verbs in the group of truth-evaluators. For the purpose of this analysis, however, they are regarded as a separate category. 


\begin{tabular}{|c|c|c|c|}
\hline & $\begin{array}{l}\text { Truth- } \\
\text {-evaluators }\end{array}$ & & \\
\hline rightly & & 5 & 5.5 \\
\hline in principle & & 3 & 3.3 \\
\hline it is possible that & & 2 & 2.2 \\
\hline merely & & 2 & 2.2 \\
\hline the fact remains & & 2 & 2.2 \\
\hline admittedly & & 1 & 1.1 \\
\hline clearly & & 1 & 1.1 \\
\hline essentially & & 1 & 1.1 \\
\hline legitimately & & 1 & 1.1 \\
\hline \multirow[t]{2}{*}{ possibly } & & 1 & 1.1 \\
\hline & $\begin{array}{l}\text { Other ways } \\
\text { of signalling }\end{array}$ & & \\
\hline emphatic 'do' & & 4 & 4.4 \\
\hline TOTAL & & 91 & \\
\hline
\end{tabular}

Appendix 2

Examples of Concessive sequences found in the corpus

A. Concession in the Court's own argumentation

\section{Example 1}

Monadic Schema (M1)

(E-10, Judgment C-217/05, 14 December 2006)

0 [Implied claim: The Court has no jurisdiction to review the case.]

A: $\quad \mathbf{X}^{\prime} \quad$ In that context, it must be recalled that the Court has no jurisdiction to give a ruling on the facts in an individual case or to apply the rules of Community law which it has interpreted to national measures or situations, since those questions are matters within the jurisdiction of the national court (see, in particular, Case 253 / 03 CLT-UFA [2006] ECR I-1831, paragraph 36, and Case C-451 / 03 Servizi Ausiliari Dottori Commercialisti [2006] ECR I-2941, paragraph 69).

Y Nevertheless, in order to give a useful answer to the national court, it is appropriate to set out the criteria enabling an assessment to be made as to the actual allocation of the financial and commercial risks between service-station operators and the fuel supplier under the agreements at issue in the main proceedings, for the purposes of determining whether Article 85 of the Treaty is applicable to them.

\section{Example 2}

Pseudo-Dyadic Schema (PD)

(E-8, Judgment No. C-150 / 05, 28 September 2006)

A: $\quad \mathbf{X} \quad$ In the case of offences relating to narcotic drugs, the quantities of the drug that are at issue in the two Contracting States concerned or the persons alleged to have been party to the acts in the two States are not 
required to be identical.

$\mathbf{X}$ It is therefore possible that a situation in which such identity is lacking involves a set of facts which, by their very nature, are inextricably linked.

X In addition, the Court has already held that punishable acts consisting of exporting and of importing the same narcotic drugs and which are prosecuted in different Contracting States party to the CISA are, in principle, to be regarded as 'the same acts' for the purposes of Article 54 (Van Esbroeck, paragraph 42).

Y However, as rightly pointed out by the Netherlands Government, the definitive assessment in this regard is a matter for the competent national courts which are charged with the task of determining whether the material acts at issue constitute a set of facts which are inextricably linked together in time, in space and by their subject-matter (Van Esbroeck, paragraph 38).

\section{Example 3}

Reversed Monadic Schema (RM1)

(E-3, Judgment No. C-237 / 04, 23 March 2006)
$\mathbf{0}$
[Implied claim: Sotacarbo is an economic entity.]
A: $\quad$ Y- In this instance,
$\mathbf{X}$ although it is for the national court to make the final assessment in this respect,
-Y various aspects of the documents available to the Court indicate that Sotacarbo's activity is liable to be of an economic nature.
(...) (...)
Y' In those circumstances, it is possible that Sotacarbo does carry out an economic activity, and, consequently, it is liable to be regarded as an undertaking for the purpose of Article 87(1) EC.

\section{Example 4}

Reversed Pseudo-Dyadic Schema (RPD)

(E-7, Joined Cases C-392 / 04 and C-422 / 04, 19 September 2006)

A: $\quad \mathbf{X} \quad$ It should be noted in that regard that Directive 97 / 13 was repealed by Article 26 of Directive 2002 / 21 with effect from 25 July 2003 in accordance with the second subparagraph of Article 28 (1) of the latter directive.

Y It follows, however, from reading Article 26 and the second subparagraph of 28 (1) of Directive 2002 / 21 that the legislature did not intend to prejudice the rights and obligations arising under Directive 97 / 13 and that Directive 2002 / 21 applies only to legal situations arising from 25 July 2003.

Y'- Consequently,

X despite the fact that Directive 97 / 13 was repealed by Directive 2002 / 21 ,

-Y the validity of a charge such as that imposed on i-21 and Arcor by the fee assessments of 14 June 2000 and 18 May 2001 respectively, at 
a time when Directive 2002 / 21 was not yet applicable, has to be examined in the light of Article 11 (1) of Directive 97 / 13.

\section{B. Reported Concession}

\section{Example 1}

Pseudo-Dyadic Schema (PD)

(E-9, Judgment C-105 / 02, 5 October 2006)

A: $\quad \mathbf{X} \quad$ By this plea, the Commission essentially criticises the German authorities for having waived unilaterally their rights to legal recovery from the guaranteeing associations of the established claims relating to the TIR carnets covered by the present proceedings, for having made incorrect accounting entries for the corresponding own resources by not entering them in the A accounts, and for having failed to make them available to the Commission in a timely manner, contrary to, inter alia, Article 17 (1) of Regulation No 1552 / 89.

X The Court notes from the outset that the German Government does not deny that the legal recovery proceedings relating to the TIR carnets in dispute were suspended, or were not brought, because agreements had been concluded with the guaranteeing associations by which the German authorities provisionally waived the right to enforcement of their claims.

X' The German Government further acknowledges that the amount of the corresponding claims was entered in the B accounts and that those claims, arising from TIR operations, were established definitively between 1993 and 1995, with the result that they were established entitlements within the meaning of Article 2 (1) of Regulation No 1552 / 89.

Y The German Government denies, however, that it thereby breached its obligations under Regulation No 1552 / 89.

\section{Annotation symbols used in the analysis:}

A: - author / participant (here: the Court)

$\mathrm{X}$ - claim

$X^{\prime}-$ acknowledgment (concession / act of conceding)

$\mathrm{Y}$ - counterclaim

$\mathrm{Y}^{\prime}$ - return to the counterclaim

Y- - syntactically incomplete countermove (counterclaim)

$-Y^{\prime}$ - return to the counterclaim as syntactic continuation of the countermove

Patterns:

PD - Pseudo-Dyadic Schema

RPD - Reversed Pseudo-Dyadic Schema 
M 1 - Monadic Schema

RM1 - Reversed Monadic Schema 1

RM2 - Reversed Monadic Schema 2

[...]-Analyst's comment

\section{Primary sources}

1. E-1, Judgment No. C-2 / 05, 26 January 2006 (Social security for migrant workers)

2. E-2, Judgment No. C-294 / 04, 16 February 2006 (Social policy)

3. E-3, Judgment No. C-237 / 04, 23 March 2006 (State aid)

4. E-4, Joined Cases C-317 / 04 and C-318 / 04, 30 May 2006 (Transport)

5. E-5, Judgment No. C-466 / 04, 15 June 2006 (Social security for migrant workers)

6. E-6, Judgment C-60 / 05, 8 June 2006 (Environment and consumers)

7. E-7, Joined Cases C-392 / 04 and C-422 / 04, 19 September 2006 (Freedom to provide services)

8. E-8, Judgment No. C-150 / 05, 28 September 2006 (Police and judicial cooperation in criminal matters)

9. E-9, Judgment No. C-105 / 02, 5 October 2006 (Communities own resources)

10. E-10, Judgment No. C-217 / 05, 14 December 2006 (Competition).

(Downloaded from: http://curia.europa.eu/jurisp/cgi-bin/form.pl?lang=en, Date of access: 20 September 2008)

\section{References}

Barth D. 2000. "that's true, although not really, but still”: Expressing concession in spoken English. - Couper-Kuhlen E., Kortmann B. (eds.) Cause, condition, concession, contrast: cognitive and discourse perspectives. Berlin: 411-437.

Barth-Weingarten D. 2003. Concession in spoken English. On the realisation of a discourse pragmatic relation. Tübingen.

Bhatia V.K. 1993. Analysing genre. Language in use in professional settings. London.

Bhatia V.K. 2002. Applied genre analysis: a multi-perspective model. - IBÉRICA 4.2002: 3-19.

Crevels M. 2000. Concessives on different semantic levels: A typological perspective. Couper-Kuhlen E., Kortmann B. (eds.) Cause, condition, concession, contrast: cognitive and discourse perspectives. Berlin: 313-339.

Couper-Kuhlen E., Thompson S.A. 1999. On the concessive relation in conversational English. - Neumann F.W., Scheulting S. (eds.) Anlistentag 1998 Erfurt Proceedings. Trier: 29-39.

Couper-Kuhlen E., Thompson S.A. 2000. Concessive patterns in conversation. - CouperKuhlen E., Kortmann B. (eds.) Cause, condition, concession, contrast: cognitive and discourse perspectives. Berlin: 381-410.

Couper-Kuhlen E., Kortmann B. (eds.) 2000. Cause, condition, concession, contrast: cognitive and discourse perspectives. Berlin.

Ford C.E. 1994. Dialogic aspects of talk and writing: because on the interactive-edited continuum. - Text 14.4: 531-554. [quoted in: Barth-Weingarten D. 2003. Concession in spoken English. On the realisation of a discourse-pragmatic relation. Tübingen]. 
Grochowski M. 1976. O strukturze semantycznej przyzwolenia. - Mayenowa M.R. (ed.) Semantyka tekstu i języka. Wrocław: 25-237.

Grote B. et al. 1997. Ma(r)king concessions in English and German. - Discourse Processes 24: $87-117$.

Halliday M.A.K., Hasan R. 1976. Cohesion in English. London.

Knott A. 1996. A data-driven methodology for motivating a set of coherence relations. [unpublished Ph.D. diss.]. University of Edinburgh.

Knott A., Dale R. 1994. Using linguistic phenomena to motivate a set of coherence relations. - Discourse Processes 18: 35-62.

König E. 1988. Concessive connectives and concessive sentences: cross-linguistic regularities and pragmatic principles. - Hawkins J.A. (ed.) Explaining language universals. New York: 321-349.

König E., Siemund P. 2000. Causal and concessive clauses: Formal and semantic relations. Couper-Kuhlen E., Kortmann B. (eds.) Cause, condition, concession, contrast: cognitive and discourse perspectives. Berlin: 341-360.

Kurzon D. 1997. 'Legal language': varieties, genres, registers, discourses. - International Journal of Applied Linguistics 7.2: 119-139.

Le Ch. et al. 2008. Contrastive analysis of Chinese and American court judgments. - Critical Approaches to Discourse Analysis across Disciplines 2.1: 49-58. [Available at: http://cadaad.rg/ejournal]

Łyda A. 2007. Concessive relation in spoken discourse. A study into academic spoken English. Katowice.

Mann W., Thompson S.A. 1988. Rhetorical structure theory: toward a functional theory of text organization. - Text 8.3: 243-281.

Mazzi D. 2005. Grounds and reasons. Argumentative signals in judicial texts. - Linguistica e Filologia 20: 157-178.

Mazzi D. 2006. “This is an attractive argument, but ...”: argumentative conflicts as an interpretive key to the discourse of judges. - Bhatia V.K., Gotti M. (eds.) Explorations in specialised genres. Bern: 271-290.

Mazzi D. 2007. The construction of argumentation in judicial texts: combining a genre and a corpus based perspective. - Argumentation 21: 21-38.

Oates S.L. 2000. Multiple discourse marker occurrence: creating hierarchies for natural language generation. - ACM International Conference Proceeding Series. [vol. V Proceedings of the workshop on student research]. Seattle, Wa: 41-45.

Pincoff E. 1971. The audiences of the judge. - Hubien H. (ed.) Legal reasoning (Proceedings of the world congress for legal and social philosophy). Bruxelles: 337-344.

Pisarkowa K. 1974. O stosunkach między parataksą i hipotaksą. Na przykładzie polskich zdań przeciwstawnych i przyzwalających. - Język Polski 54.2: 81-93.

Porter J.E. 1986. Intertextuality and the discourse community. - Rhetoric Review 5.1: 34-47.

Quirk R., Greenbaum S. 1973. A university grammar of English. Harlow.

Rudolph E. 1996. Contrast: adversative and concessive relations and their expressions in English, German, Spanish and Portuguese on sentence level and text level. Berlin, New York.

Sanders T.J.M. et al. 1992. Towards a taxonomy of coherence relations. - Discourse Processes 15: 1-35.

Swales J.M. 1990. Genre analysis. English in academic and research settings. Cambridge.

Taboada M. 2006. Discourse markers as signals (or not) of rhetorical relations. - Journal of Pragmatics 38.4: 567-592.

Thompson G., Zhou J. 2000. Evaluation and organisation in text: The structuring role of evaluative disjuncts. - Hunston S. (ed.) Evaluation in text: authorial stance and the construction of discourses. Oxford: 121-141. 
Vannier G. 2001. Argumentation et droit. Introduction à la nouvelle rhétorique de Perelman. Paris. [quoted in: Mazzi D. 2007. The construction of argumentation in judicial texts: combining a genre and a corpus based perspective. - Argumentation 21: 21-38].

Verhagen A. 2000. Concession implies causality, though in some other space. - Couper-Kuhlen E., Kortmann B. (eds.) Cause, condition, concession, contrast: cognitive and discourse perspectives. Berlin: 361-380. 